\title{
Sectoral social dialogue at EU level - recent results and implementation challenges
}

\author{
Sabrina Weber \\ Department of Politics and Management, University of Konstanz
}

\begin{abstract}
Summary
This article deals with recent developments in EU social dialogue, namely so-called 'new generation texts', which are non-binding legally, but 'implementation-oriented'. Aspects of their follow-up, implementation and multi-level characteristics are therefore discussed. Findings from two sectoral dialogues indicate that follow-up procedures can vary considerably. Furthermore, the implementation or impact of such 'new generation texts' seem hard to prove. It is argued that characteristics of national industrial relations systems are insufficient to explain implementation results, since both the interests and attitudes of the actors involved and the specific topic of a given 'new generation text' must be taken into account. The main difficulty is found to be the lack of adequate implementation structures due to missing inter- and intraorganizational 'level linkage’.
\end{abstract}

\section{Résumé}

Cet article traite de récents développements du dialogue social européen, à savoir les « textes de la nouvelle génération », qui ne sont pas légalement contraignants, mais « orientés vers la mise en œuvre » (implementation-oriented); il analyse certains aspects du suivi et de la mise en œuvre et les spécificités d'une problématique à niveaux multiples. L'observation de deux dialogues sectoriels montre que les procédures de suivi peuvent considérablement varier. D'autre part, la mise en œuvre ou l'impact d'un « texte de la nouvelle génération " semblent difficiles à déterminer. L'auteur estime que les caractéristiques des systèmes nationaux de relations professionnelles ne suffisent pas pour expliquer les résultats de mise en œuvre: il faut tenir compte à la fois des intérêts et des attitudes des acteurs impliqués et de la thématique spécifique d'un « texte de la nouvelle génération ». La principale difficulté réside dans le manque d'adéquation des structures de mise en oeuvre dû à l'absence d'articulation des niveaux entre et au sein des organisations.

Corresponding author:

Sabrina Weber, Doctoral candidate, University of Konstanz, Department of Politics and Management, Box 83, 78457 Konstanz, Germany

Email: sabrina.weber@uni-konstanz.de 


\begin{abstract}
Zusammenfassung
Dieser Beitrag befasst sich mit den jüngsten Entwicklungen des sozialen Dialogs auf EU-Ebene, insbesondere „Vereinbarungen der neuen Generation", das heißt Vereinbarungen, die zwar nicht rechtsverbindlich, aber dennoch "implementationsorientiert" sind. In diesem Zusammenhang werden verschiedene Aspekte von Folge- und Implementationsmaßnahmen und Merkmale der Beziehungen zwischen den verschiedenen Ebenen erörtert. Die Untersuchung des sozialen Dialogs in zwei Branchen zeigt, dass Verfahren für Folgemaßnahmen äußerst unterschiedlich sein können. Die Implementation bzw. Auswirkungen einer „Vereinbarung der neuen Generation“ sind nur schwer zu belegen. Neben Merkmalen der nationalen Systeme der Arbeitsbeziehungen müssen die Interessen und Strategien der beteiligten Akteure sowie die spezifische Thematik der betreffenden Vereinbarungen in die Erklärung einbezogen werden. Das Hauptproblem besteht in fehlenden adäquaten Implementationsstrukturen, da häufig weder innerhalb noch zwischen den betreffenden Organisationen die relevanten Ebenen miteinander verknüpft sind.
\end{abstract}

\title{
Keywords
}

European Union, social dialogue, implementation

\section{Introduction}

In recent years, a new variety of joint outcomes has emerged within the framework of social dialogue at EU level, ${ }^{1}$ referred to by the European Commission as 'new generation texts'. These joint texts are non-binding legally, but rather 'implementation-oriented' and therefore directed towards the national affiliates of European organizations. This article discusses aspects of follow-up, implementation and monitoring of such 'new generation texts' within their complex multi-actor and multi-level setting. In this respect, the attitudes of European and national actors and the 'linkage' between the different levels involved play a decisive role. How do social partners at both the supranational and the national levels approach these joint texts? What measures for follow-up and monitoring of the texts are taken? What factors account for the implementation or nonimplementation of 'new generation texts'?

The article is structured as follows. In Section 1, an overview of social dialogue at EU level and recent developments in this field of European industrial relations is provided. In Section 2, recent research on EU social dialogue is summarized and a framework presented for analysing 'new generation texts'. In Section 3, empirical findings for the supranational and national levels of two sectoral social dialogues are discussed. The article concludes with a summary, including the outlook with regard to further research.

\section{Possible outcomes of social dialogue at EU level}

Social dialogue at EU level takes place, first, at interprofessional level and secondly, at sectoral level, which involves nearly 40 sectoral social dialogue committees. While the two levels are distinct in terms of historical development, a recent trend towards the conclusion of legally non-binding but implementation-oriented outcomes (autonomous agreements, codes of conduct, guidelines and so on) can be observed at both levels. These outcomes are called 'new generation

1 In this article, the notion of 'social dialogue' refers to the bipartite dialogue between the umbrella organizations of trade unions and employers' organizations at EU level. 
Table I. Results of European social dialogue - typology

\begin{tabular}{|c|c|c|}
\hline \multirow{3}{*}{$\begin{array}{l}\text { Social dialogue results - types } \\
\text { of texts/categories } \\
\text { I. Agreements in accordance } \\
\text { with Article 139(2): } \\
\text { minimum standards }\end{array}$} & \multicolumn{2}{|c|}{ Implementation and monitoring } \\
\hline & a) Council decision & $\begin{array}{l}\text { Member States responsible for transposition and } \\
\text { implementation (even where implemented by col- } \\
\text { lective bargaining); monitoring by the Commission }\end{array}$ \\
\hline & $\begin{array}{l}\text { b) Autonomous } \\
\text { agreements* }\end{array}$ & $\begin{array}{l}\text { Implemented in accordance with the procedures and } \\
\text { practices specific to management and labour and } \\
\text { the Member States } \\
\text { Social partners responsible for implementing and } \\
\text { monitoring }\end{array}$ \\
\hline \multirow[t]{3}{*}{ II. Process-oriented texts* } & $\begin{array}{l}\text { a) Frameworks of } \\
\text { action }\end{array}$ & $\begin{array}{l}\text { Identification of certain policy priorities; these prio- } \\
\text { rities serve as benchmarks } \\
\text { Follow-up and annual reporting by the social } \\
\text { partners }\end{array}$ \\
\hline & $\begin{array}{l}\text { b) Guidelines, } \\
\text { codes of } \\
\text { conduct }\end{array}$ & $\begin{array}{l}\text { Recommendations and/or guidelines to national } \\
\text { affiliates concerning the establishment of standards } \\
\text { or principles } \\
\text { Regular follow-up and reporting by the social } \\
\text { partners }\end{array}$ \\
\hline & $\begin{array}{l}\text { c) Policy } \\
\text { orientations }\end{array}$ & $\begin{array}{l}\text { Proactive promotion of policies } \\
\text { Regular follow-up and reporting by the social } \\
\text { partners }\end{array}$ \\
\hline \multirow[t]{3}{*}{ III. Joint opinions and tools } & a) Joint opinions & $\begin{array}{l}\text { Provide input to the European institutions and/or } \\
\text { national public authorities; } \\
\text { No implementation, monitoring or follow-up } \\
\text { provisions }\end{array}$ \\
\hline & b) Declarations & $\begin{array}{l}\text { Outlining future work and activities which the social } \\
\text { partners intend to undertake } \\
\text { No implementation, monitoring or follow-up } \\
\text { provisions }\end{array}$ \\
\hline & c) Tools & $\begin{array}{l}\text { Practical advice to employees and companies } \\
\text { Exchange knowledge of good practice } \\
\text { No implementation, monitoring or follow-up } \\
\text { provisions }\end{array}$ \\
\hline IV. Procedural texts & & Rules governing bipartite dialogue between parties \\
\hline
\end{tabular}

Note: * Texts of type lb and II are called 'new generation texts' by the Commission.

Source: Weber (2008), 55 (in accordance with European Commission, 2004: Annex 2).

texts' by the European Commission (see Table 1, categories Ib, II). ${ }^{2}$ The various possible outcomes and the often ambiguous use of terms such as 'agreement' or 'declaration' in EU social dialogue

2 According to the Commission typology (see Table 1), 'new generation texts' can be further differentiated into, on the one hand, 'autonomous agreements' (Ib) that are Treaty-based (Article 155 TFEU; former Article 139 TEC) but lack - in contrast to 'social partner directives' (Ia) - legal bindingness; and, on the other hand, three kinds of 'process-oriented texts' (II). However, in the social partners' perception and in terms of implementation this differentiation is rather formal in nature (Weber, 2008; a similar observation has been made by Léonard et al., 2007: 49). In its most recent document on sectoral social dialogue (European Commission, 2010), the Commission does not use the term 'new generation texts' any longer but only 'agreements' and 'process-oriented texts'. 
have prompted a Commission proposal for a more coherent denomination (a slightly different typology of outcomes has been provided by the Observatoire Social Européen (OSE); for a discussion of the empirical relevance of both typologies, see the Preliminary conclusion below). Furthermore, the Commission has issued a 'checklist' for designing social partner texts: recommendations include the specification of addressees and follow-up provisions (see Table 2).

The term 'new generation texts' refers, first, to joint documents directed not towards EU institutions but rather towards the national members of the organizations concerned. Secondly, the implementation of these documents is to be managed by the social partners themselves, without the participation of EU institutions, which distinguishes them from 'social partner directives' (see Table 1, category Ia). At the sectoral level of EU social dialogue, which will be the focus of this article, almost 60 'new generation texts' (four autonomous agreements (including a multi-sectoral one), 10 codes of conduct, 32 guidelines and 13 policy orientations) have been concluded within the sectoral social dialogues. The development of 'new generation texts' can be set in the context of the 'Lisbon strategy', endorsed in 2000, which marked an overall shift in EU regulation, highlighting non-binding, 'soft' approaches and the principle of subsidiarity (European Council, 2000). Recent developments in social dialogue have taken place within this changed regulatory' context. In order to enhance the implementation of 'new generation texts', the social partners, therefore, need to develop monitoring and evaluation mechanisms. In doing so, they may draw on the open method of coordination (Branch, 2005: 325-326). ${ }^{3}$

To sum up, 'new generation texts' constitute a new development in social dialogue at EU level in recent years. In general, social dialogue outcomes prior to this development fell into the two distinct categories of (i) joint positions, addressed to the Commission, or (ii) agreements (albeit few in number) transposed into 'social partner directives' and therefore legally binding (see Table 1).

\section{State of play and recent research on social dialogue}

Research on EU social dialogue has long concentrated on the supranational level of EU social dialogue - mainly the interprofessional social dialogue - describing actors, processes and results at EU level. The few instances of implementation research have concentrated on legally binding 'social partner directives' (Falkner et al., 2005; Leiber, 2005), although the challenges related to the implementation of 'new generation texts' by the social partners themselves have been noted by some observers (for example, Dufresne et al., 2006; Keller, 2003; Léonard et al., 2007). The Commission reacted very positively to 'new generation texts' (European Commission, 2004: 6). Some observers have also discerned a lot of potential in these recent developments, such as further developing a 'specifically European' (Jacobi and Kirton-Darling, 2005: 341) social dialogue model with trade unions playing a proactive role. Others have been more cautious and critical concerning 'new generation texts' and the existing framework for social dialogue, thereby raising issues such as the unclear nature of the texts, the problem of organizational capacities and enforceability, or patchy coverage rates when implementing these texts (Blanpain, 2007; Keller, 2005; Smismans, 2008; for an overview see also Marginson, 2005).

Only very recently has the focus of academic researchers and European institutions started to go beyond the processes at supranational level and attention has shifted to the impact and

3 For a discussion of the most recent developments in EU social dialogue in the context of various 'soft' modes of EU regulation, see Weber (2010). For a wider debate on the European economic and social model and the context of the Lisbon strategy, see, for example, the contributions to the Special Issue on Governing Europe of the International Journal of Public Policy (2008), 3(1/2). 
Table 2. Checklist for 'new generation texts'

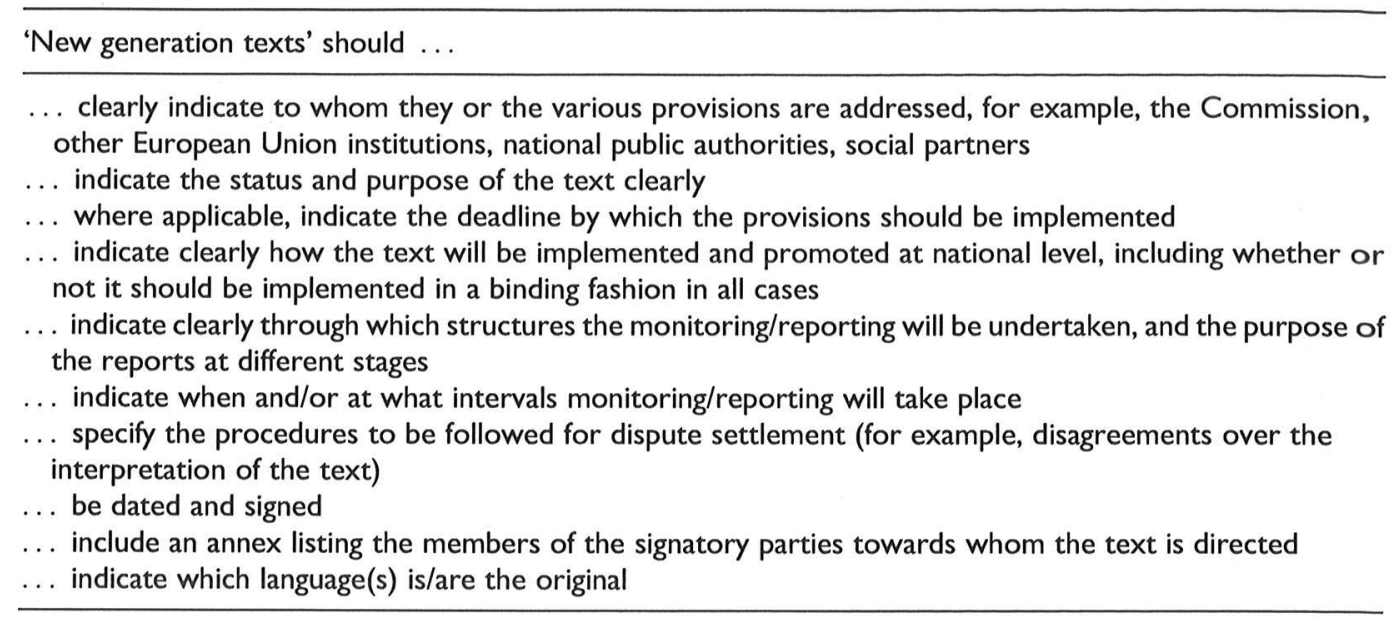

Source: Based on European Commission (2004): Annex 3.

implementation of social dialogue results at the lower levels and the interplay between these levels. This may be illustrated by several Commission projects, initiatives and documents aimed at exploring and fostering implementation, such as the European Social Fund 2007-2013, the ex-post evaluation on behalf of the Commission of the implementation of the interprofessional telework agreement (Visser and Ramos Martin, 2008) and a chapter explicitly dedicated to the implementation of social dialogue results in the Commission's most recent biannual 'Industrial Relations in Europe' report (European Commission, 2009). Secondly, a growing number of research studies have provided initial evidence concerning the implementation of 'new generation texts' concluded at the interprofessional level of EU social dialogue that point to implementation measures that are quite diverse in form and scope. These include Larsen and Andersen (2007), which provides a comparative analysis of the implementation of the interprofessional autonomous agreement on telework; Prosser (2007), which concerns the implementation of the interprofessional agreements on telework and stress in the UK and Denmark; Deakin and Koukiadaki (2007), which deals with the telework agreement in the UK; and Niforou (2008), which addresses the role of trade unions when implementing the telework agreement in Spain and the UK.

In contrast, the sectoral level of EU social dialogue has long been neglected by many researchers and the Commission (European Commission, 1993). Only recently has it attracted wider interest also in the context of research on the implementation of 'new generation texts' (Léonard, 2008; Larsen and Navrbjerg, 2009 focusing on the banking sector; Murhem, 2008 for sectoral social dialogue in Sweden, providing insights from a trade union perspective; a recent European Foundation for the Improvement of Living and Working Conditions research project (Pochet et al., 2009) and the recent Commission consultation on the European sectoral social dialogue with regard to a most recent Commission staff working document on sectoral social dialogue finally published in summer 2010 (European Commission, 2010).

However, in empirical terms, it is still generally unclear what problems and effects actually arise when sectoral social partners implement 'new generation texts'. In order to investigate the potential challenges, the focus adopted in this article is on the implementation processes at the 
various levels: how do the social partners handle these texts and what factors determine the implementation or non-implementation of 'new generation texts'? The aim of this article is to contribute to closing the research gap by discussing aspects of monitoring and implementation and by providing in-depth evidence from a qualitative study of recent processes and activities in two sectoral social dialogues. ${ }^{4}$ The empirical findings are based on document analysis, expert interviews with actors at supranational and national level and non-participatory observation in the electricity and commerce social dialogues. ${ }^{5}$ These dialogues were chosen because they have been very active in concluding 'new generation texts' (see Table 3). ${ }^{6}$ With regard to the national level, three Member States that represent different systems of industrial relations have been taken into account (Denmark, Germany and the UK). ${ }^{7}$ The findings presented below refer to these cases and therefore cannot be generalized 'without further ado'.

It is assumed that the characteristics of the respective national systems of industrial relations influence the handling of 'new generation texts' by national social partners. Within the framework of an actor-centred approach, however, the institutional context - the national system of industrial relations - must be understood "in the dual sense of "limiting" and "enabling" (Müller-Jentsch, 2004: 34) and therefore structures, but never determines, actors' behaviour (Mayntz and Scharpf,

4 This article therefore focuses on the (vertical) relations between supranational and national social partner organizations; a discussion of the 'horizontal' relationships ('synergies', European Commission, 2004) between the interprofessional and the various sectoral social dialogues and between sectoral dialogues would go beyond the scope of this article.

5 The research methods include face-to-face semi-structured interviews (2006-2008) with representatives of the supranational organizations involved in the respective sectoral dialogues, representatives of national affiliates and Commission officers, the analysis of social partner documents, Commission documents, and social dialogue meeting minutes and related documents. Non-participatory observation of two plenary EU social dialogue meetings in both sectors and preparatory meetings of trade unions and employers in one sector (2007-2008) provide a complementary source of data.

6 Both sectors are characterized, on the one hand, by large multinational companies and, on the other, by the existence of many small and medium-sized enterprises. Whereas the commerce sector can be regarded as a 'big player' in terms of number of employees (around 30 million within the EU) but comparatively unaffected by EU policies, the electricity sector is characterized by reductions in employment following the EU's liberalization policy. EU climate policy also impacts the sector. Case selection at the supranational level followed a 'quantitative' strategy - the sectoral social dialogues in commerce and electricity have been the most active ones in concluding 'new generation texts' on a variety of topics - for two reasons. First, this strategy suits the study's aim of conducting in-depth sectoral studies to explore the roles and views of actors at the different levels, but at the same time of including as many 'new generation texts' as possible, thereby accounting for the assumption that the topic of a 'new generation text' might play an important role in implementation. Secondly, in this respect, since it is generally unclear whether and how 'new generation texts' trigger implementation activities at the national level, it is appropriate to follow this 'quantitative' strategy in terms of number of 'new generation texts', but at the same time to reduce the number of specific sectoral contexts to two in order to reduce the number of possible explanatory variables.

7 For reasons of comparability, only 'old' EU Member States with 'established' systems of industrial relations were selected. Further research could review the empirical results for 'new' Member States. The characteristic differences between the national industrial relations systems in the three countries chosen (such as bargaining coverage, main level for collective bargaining, role of social partners and legal regulation) suggest that the implementation of 'new generation texts' could be expected to be most unproblematic in Denmark and most difficult in the UK, with Germany somewhere in between. In effect, the Danish social partners welcomed the development of the autonomous social dialogue because implementation by the social partners themselves is more appropriate in the context of the Danish industrial relations system (Leiber, 2005: 253). 
Table 3. 'New generation texts' in the commerce and electricity sectoral social dialogues

\begin{tabular}{lll}
\hline Type of text & Electricity & Commerce \\
\hline Guidelines & Health \& Safety (1996/2006) & Telework (200I) \\
& Telework (2002)* & Age Diversity (2003) \\
& Harassment and Violence (2007)* & $\begin{array}{l}\text { Inclusion of Disabled (2004) } \\
\text { Stress (2007)* }\end{array}$ \\
Policy orientation & Equality and Diversity (2003) & CSR (2004)** \\
Code of conduct & CSR (2009)** & Fundamental Rights and Principles (1999) \\
\hline
\end{tabular}

Notes:

* Refer to the respective interprofessional autonomous agreements and recommend their implementation.

** Corporate Social Responsibility.

1995: 45). As it is unclear how far the legally non-binding 'new generation texts' will lead to consequent action at both supranational and national level, this article uses the term 'implementation' in a wide-ranging sense. 'Implementation' includes all measures taken by actors at different levels aimed at facilitating or establishing compliance with a concrete 'new generation text'. 'Implementation' encompasses procedural (follow-up, monitoring, dissemination), as well as substantive (guidelines, agreements and other outcomes that take into account a specific 'new generation text') dimensions. The following section examines the empirical findings.

\section{Empirical findings: sectoral social dialogue and 'new generation texts'}

In this section, some aspects of the functioning of social dialogue committees at supranational level are highlighted, together with their multi-level aspects, before findings concerning the national level are presented. The former is of great importance for understanding the whole picture.

\section{Supranational level: actors in a complex institutional setting}

In what follows, findings will be presented on four aspects related to the supranational level: (i) the working procedures of the sectoral social dialogue committees, (ii) the role of the Commission, (iii) the impact of the EU policy context and (iv) the interests and actions of the social partner organizations' secretariats at EU level.

\section{Working procedures}

The working procedures of the sectoral dialogue committees show continuity and stability in both their strengths and weaknesses. In their practical work, the Commission's typology of social dialogue results (see Table 1) is currently not being applied systematically. The same is true of the issues listed in the Commission's checklist (see Table 2). This refers, first, to the denomination of the various results (often called 'joint statements') and, secondly, to the specification of certain clauses in the text as such. Ideally, according to the Commission's typology, texts should be directed towards national social partners and specify implementation deadlines or follow-up and monitoring provisions. In practice, such provisions are largely missing; furthermore, in many cases the question of addressees remains rather open or unclear. Social partner views on the Commission typology and checklist are quite diverse, ranging from rejecting the Commission's proposals as 'paternalistic' intervention to appraisal as a helpful clarification and 'optional framework'. 
The Commission strongly supports the conclusion of mainly biannual work programmes within the scope of the respective social dialogues. The conclusion of a work programme is mostly seen as controversial and time-consuming by the social partners, because concrete issues and measures have to be agreed upon. However, interviewees from both the Commission and social partners at supranational and national level regard these work programmes, when established, as very helpful for the smooth and target-oriented organization of the work of social dialogue committees by providing a structure and timetable. Interviewees at the supranational level, moreover, pointed out a high level of trust and reliability in the relationship between the social partners, built up over the years and helping to maintain good working methods, even when discussions are controversial.

When assessing EU social dialogue with a focus on implementation, the participation of national affiliates in social dialogue meetings is a major point of interest. While in the cases analysed there is, to some extent, stability concerning national organizations and persons, besides this 'core group' there is a relatively high degree of fluctuation in the sense that national representatives may take part in one meeting but never again. If national social partner representatives - 'core group' members - are able to take part in the dialogue meeting on a continuous basis, they seem better able to provide regular statements and to be actively involved during meetings. In general, however, representatives of national affiliates tend to be passive. Furthermore, with regard to the conclusion of 'new generation texts' and their follow-up and implementation, it is crucial to look at evaluation mechanisms developed within the sectoral dialogue. First, the evaluation can be exercised bilaterally or unilaterally. Secondly, the evaluation can have the form of a survey sent out to national affiliates (commerce), or the topic may be discussed in a more informal way (electricity). Thirdly, this evaluation can take place more or less systematically (every year, all 'new generation texts', always the same texts and so on). The general experience of EU social partners is that it is rather difficult to obtain answers from the national affiliates, particularly in written surveys. Most recently, discussions have started on how to establish structures for implementation and forms of an evaluation and monitoring framework in both sectoral dialogues. The outcome remains to be seen.

\section{Role of the Commission}

The Commission plays multiple roles within the sectoral dialogues - for example, as mediator or as 'contact broker'. First, the sectoral committee can be chaired either by the social partners in rotation (electricity dialogue) or by a representative of the Commission Directorate General Employment and Social Affairs, DG EMPL (commerce dialogue). Especially in the latter case, the Commission representative can fulfil a moderating and bridging role when discussions are controversial. However, the 'conciliatory' function is exercised mainly in an informal setting: during social dialogue meetings Commission representatives pursue a low-key moderating function. Secondly, depending on the policy context of the sectoral dialogue, the Commission representative can have the function of 'contact broker' by inviting, at the social partners' request, representatives from other departments of DG EMPL, or from other directorates general that affect the sector, such as DG Industry and Entrepreneurship, DG Energy or DG Environment, to the social dialogue meetings. In this context, social dialogue directly opens channels for 'joint inside lobbying' on sector-specific subjects that are more or less related to social dialogue.

\section{Impact of the EU policy context}

Hardly surprisingly, the EU policy context heavily influences the work of the sectoral dialogue in both procedural (working methods) and substantial (topics) terms. Topics are influenced by legislative proposals and broader EU policy initiatives (such as the European Year for Gender 
Equality and the strategy for health and safety at the workplace). Furthermore, especially in the electricity sector which is heavily affected by EU regulations, sector-specific legislative initiatives have a major impact on the work of sectoral dialogue. The sector-specific initiatives affect, first, the topics dealt with in the social dialogue (social partners tend to deny this aspect but rather underline their autonomy in all respects), and secondly, the working method used to approach a topic. Therefore, legislative initiatives concerning liberalization and climate protection trigger actions of joint lobbying by the electricity social partners, such as joint letters to the Commissioner and joint statements. In this context, the aforementioned invitation of experts from various Commission DGs plays an important role. Whereas the electricity sector lies in the 'shadow of the common market', the commerce sector is, comparatively, in the 'shadow of non-regulation': actors consider their sector and its characteristics and needs to be, to some extent, disregarded, although it is an important player not only in terms of number of employees. Therefore, actors may have an incentive to 'self-regulate'. Pochet (2007: 161) therefore claims that commerce is 'a separate case, experimenting with a variety of social dialogue instruments in a bid to better highlight its specific characteristics'.

\section{Role of EU organization secretariats}

The role of EU organization secretariats in Brussels and the interaction with their national affiliates constitute a decisive factor in the implementation of 'new generation texts', contributing - to a greater or lesser extent - to the necessary 'level linkage'. The findings from the cases analysed, which include five EU umbrella organizations, highlight the important role of the secretariats of these organizations. They act as a catalyst and filter, both towards their own national affiliates and towards EU institutions. National affiliates' activity, awareness and role during social dialogue meetings (see above) seem to be linked not only to 'national' factors (see the following section), but also, to a considerable degree, to the secretariats' information and communication policies and steering function. This points to a 'top-down' approach to the different levels. Interviewees from the Commission, EU organizations and national affiliates confirm their satisfaction with the state of play, since it seems the most realistic form of shaping interaction between levels. However, there are also more critical observers within the Commission and clearly among national affiliates who find a more 'bottom-up' approach desirable, but admit that its realization is quite hard to achieve. This fits in with the finding that secretariats face major problems when trying to foster implementation, gather information for monitoring social dialogue outcomes or motivate national affiliates to take part in meetings, displaying both the lack of a possibility to oblige affiliates and the limits of self-evaluation.

Finally, the interests of EU organizations and their national affiliates can diverge, as the 'logic of influence' (Dølvik, 1998: 330; Schmitter and Streeck, 1999) may dominate at EU level. What was said above pointed towards the sometimes divergent interests and strategies of secretariats at EU level and national affiliates. Put differently, the linkage between EU umbrella organizations and national organizations sometimes seems to be loose. For the EU secretariats, acting within the 'Brussels arena', a dominant logic of influence can result in the lack of a common understanding with national affiliates concerning the goals and necessities of processes taking place at EU level. Formally and officially, the interests and strategies of European umbrella organizations arise from the affiliates' needs and views. However, from the point of view of national interviewees - but also Commission interviewees - the organizations' EU secretariats could use this arena to pursue their specific interests and their own strategies in the game of EU sectoral social dialogue. Within this multi-level and multi-actor setting, therefore, principle-agent problems seem to occur, for example, with regard to information and transparency. However, it is not easy to identify at which level (supranational or national) the agent and at which the principal should be located. As stated above, in the view of most interviewees, a top-down approach is actually applied. 
To sum up, evidence from the supranational level leads to the conclusion that working procedures within the dialogue are stable and well established. Most recent discussions in this respect concern the implementation and systematic evaluation of 'new generation texts'. Important actors include the secretariats of EU organizations which operate as filtering, gate-keeper institutions, and the Commission, which acts as a bridge builder and 'contact broker'. National affiliates are, to various degrees, involved in the work of social dialogue and sometimes encounter problems of transparency and of understanding the processes taking place in the 'Brussels arena'.

\section{National level: organizational and institutional factors shape actors' strategies and resulting actions}

The five aspects highlighted in this section are as follows: (i) the implementation record at national level, (ii) the level of awareness of EU sectoral social dialogue, (iii) interests and attitudes of national actors, (iv) the role of the national industrial relations system and (v) the role of the topic dealt with by a specific 'new generation text'.

\section{Implementation record at national level}

Empirical evidence for the national level makes clear that it is difficult to show the concrete impact of 'new generation texts'. Implementation may take place by various means, at various levels and under the influence of a range of factors. National social partners have to be both willing to implement and capable of implementing 'new generation texts'. According to our findings, it is difficult to quantify implementation; it is unclear whether initiatives or measures related to a particular topic are directly stimulated by the social dialogue text or whether they would have been developed even in the absence of such a text. Overall, few reports are available on measures related to 'new generation texts'.

Taking the problem of self-evaluation into consideration, the number of implementation measures might be even lower, as such procedures tend to be biased in favour of the actors involved, who describe many activities as 'implementation measures'. In this respect, a 'double filtering' (Weber, 2008: $64 \mathrm{ff}$ ) is at work: first, national affiliates report to EU umbrella organizations, trying to draw the most positive picture of measures undertaken. Secondly, the latter report jointly to the Commission, again trying to draw the most positive overall picture of implementation measures vis-à-vis EU institutions. As the Commission supports EU social dialogue in both technical and financial terms, and currently emphasizes implementation issues, actors have a major interest in presenting themselves as successful implementers.

Interestingly, and in sharp contrast to the classification of social dialogue results provided by the Commission (see Table 1), national affiliates do not necessarily regard 'new generation texts' as 'implementation-oriented' outcomes of the EU sectoral dialogue, but consider so-called 'tools' (see Table 1, category IIIc) to be much more implementation-oriented. Moreover, national affiliates appreciate the knowledge generating function and the information exchange among and between trade unions and employers during these projects. Overall, empirical evidence suggests that the impact of 'new generation texts' may be smaller at national level than the impact of such 'tools', in respect of which social partners have worked out recommendations and checklists for a certain topic, for example, on equality and diversity (2006) in the electricity sector and on safety (2009) in the commerce sector. In this respect, existing typologies of social dialogue results should be interpreted more flexibly in empirical terms (see Preliminary conclusion). 


\section{Level of awareness of EU sectoral social dialogue}

The level of awareness and systematic institutionalization of EU social dialogue within national organizations is decisive for the implementation of 'new generation texts'. As noted above, the first and most crucial point for the implementation of "new generation texts' is the link between the supranational and the national level. In this respect, apart from the EU secretariats' concrete efforts to inform and involve affiliates, the awareness and knowledge of the national actors potentially involved in EU social dialogue is important: does at least one person know about the work and results of the respective sectoral dialogue? Are other people within the organization aware of 'new generation texts'? For pragmatic reasons, the awareness level in national organizations cannot be analysed easily, since it is not possible to conduct interviews in all departments and at all levels of an organization. Therefore, the assessment of the interviewees must be used to measure awareness throughout the organization: all interviewees at the national level reported a fairly low level of awareness and an insulated role for EU social dialogue within the organization. In general, awareness is limited to a few people active in this field within the EU umbrella organization. Even colleagues quite active in the EU umbrella organization, but in other policy fields, may not know about the respective EU social dialogue.

Nevertheless, field experience can furnish evidence 'through the back-door'. Our findings show three kinds of ignorance: (i) representatives of the national affiliated organization might not even know what social dialogue at EU level means; (ii) it can be the case that, although people know about the existence of EU social dialogue, no one in the organization is responsible for it; and (iii) it can happen that there is indeed at least one person that deals with EU social dialogue, but colleagues - even in the same department - might not be aware of this. This low awareness points to the particular interests and attitudes of national actors regarding EU social dialogue, as addressed in the following section.

\section{Interests and attitudes of national social partners}

Empirical evidence points to certain interests and attitudes of national social partners that influence the implementation or non-implementation of 'new generation texts'. These interests and attitudes depend to a considerable degree both on national settings and on the topic of a given 'new generation text'.

In general, although national social partners bear witness to an overall increase in the importance of EU-related topics and the EU level in general for their work, they attribute only a minor role to EU social dialogue in this context. This is reflected in the aforementioned fact that EU social dialogue is relatively unknown in national organizations. Related considerations include limited human resources and the priority of 'national' topics over 'European' ones. National representatives active in the EU sectoral dialogue often experience a lack of understanding and appreciation within their own organization towards their work ('for most people, social dialogue at EU level is a long way off'). Overall, however, social dialogue is perceived favourably by interviewees, who identify its value added as consisting mainly of mutual learning, the dissemination of best practices and the provision of resources, such as joint studies and 'tools'. In practical terms, this value added remains limited, however, as implementation and awareness of the social dialogue are still weak.

According to our findings, the social partners assign different functions to EU social dialogue and may have certain reservations vis-à-vis possible linkages between the supranational social dialogue and processes 'at home'. Some national affiliates - employers' organizations as well as trade unions - do not necessarily think that the main goal of sectoral social dialogue at EU level should be the conclusion of legally binding or even legally non-binding 'agreements' (or even that it 
should be any kind of goal at all). Our findings rather support the thesis that an important function of sectoral social dialogue is the possibility jointly to lobby European institutions (De Boer et al., 2005). Our case studies show a strong preference among national trade union representatives for a lobbying element in sectoral social dialogue, especially - and unsurprisingly - in the electricity sector, which is strongly affected by EU policies. Therefore, findings do not support analyses that assign a preference for lobbying only or mainly on the part of employers' organizations (Dufresne, 2006).

\section{Role of the national industrial relations system}

The national system of industrial relations is the main point of reference for national social partners and strongly shapes their interests and resulting strategies concerning EU social dialogue and 'new generation texts'.

For Danish actors, for example, this means that, on the one hand, they try to bring elements of their home model, which is characterized by strong organizations and a voluntaristic-cooperative partnership, to the EU level ('uploading'); and on the other hand, that both employers and trade unions in Denmark are fairly sceptical of legislation in the field of industrial relations. This applies in particular to EU-level regulation. Interviewees considered the Danish system of industrial relations, based on strong organizations and agreements rather than legislation, to be very satisfying and even superior to other (national or supranational) systems of industrial relations. Therefore, there are general reservations concerning regulation at EU level, be it legislative or nonlegislative. Concerning 'new generation texts', Danish interviewees identify the main problem as the fact that only social partners in the Nordic countries will 'take them seriously', since they are legally non-binding.

For German actors, taking the national system as main point of reference means that the legally non-binding nature of social dialogue outcomes is regarded mainly as a weakness by the trade unions, but as a plus by the employers, who claim that it 'allows for flexible solutions'. Moreover, trade union representatives in Germany have expressed concerns that the implementation of "new generation texts' might limit their room for manoeuvre in national bargaining processes. This may explain the reservations of some trade unionists.

For British trade unions, the fact that sectoral structures of collective bargaining do not exist in the private sector 'at home' means that the EU dialogue at sectoral level is of rather limited importance from their point of view. Some representatives even take the view that EU sectoral dialogue does not constitute an adequate tool or transnational forum at all. Some trade unionists, including those in the electricity sector, prefer bilateral, in-depth cooperation with other national trade unions, aimed at better cooperation at the level of multinational companies within the sector.

All national interviewees emphasized the relevance of well-established customs and practices for the (potential) implementation of a 'new generation text'. This must also be seen in the context of the particular topic of given 'new generation texts': which levels and which measures are regarded as adequate at all?

\section{Role of the topic addressed by a specific 'new generation text'}

Due to possible (over-)compliance, as well as varying relevance from the point of view of the social partners, the particular topic of a given 'new generation text' plays a major role in implementation. From the point of view of social partners in Denmark and Germany and, to a lesser extent, in the UK, in general, 'new generation texts' are already complied with. Therefore, there is no need for implementation. Overall, interviewees feel that 'new generation texts' might have 
a major impact in the new EU Member States, where the level of (over-)compliance is regarded as much lower (but see Conclusion and outlook below).

The topic addressed by a given 'new generation text' is relevant for the level and form of implementation measures. Experience of similar topics may shape implementation. In the case of Germany, social partner representatives considered works agreements much more adequate for the telework issue than a collective agreement. In the Danish commerce sector, some contents of 'new generation texts' are discussed bilaterally. If social partners consider it appropriate, aspects that are not yet incorporated in collective agreements can be taken into account, as was the case with regard to age diversity. However - and here the interests of the actors involved play a major role-there is no reference to 'European roots'. A similar example can be found in the German commerce sector. Here, certain topics dealt with in the EU sectoral dialogue are discussed between the social partners - for example, the topic of a 'safer shopping environment' within a mutual insurance association but no reference is made to European documents or processes. The reason is that representatives feel that such a European reference might, if anything, hamper discussions ('we always try to avoid to say ... "here are the European issues" ... because then people switch off').

To sum up, evidence for the national level points to rather limited implementation structures and activities. The reasons are found to be the low level of awareness, actors' interests and strategies embedded in the national system of industrial relations, and the role and resources they bestow on the EU sectoral dialogue. Furthermore, the topic - but also the type of a 'new generation text' seems to be important. Finally, according to our case studies, the commitment of individuals at the various levels involved is decisive for the functioning of and coping with EU social dialogue: the status quo may, therefore, change according to personnel changes within organizations. This leads to the conclusion that EU social dialogue is not (yet) systematically embedded in organizational structures and policies, but is dealt with individually or on a case-by-case basis, especially by national organizations.

\section{Preliminary conclusion: implementation structures and institutionalization are lacking, but the focus of attention is shifting}

The empirical evidence presented above leads to the overall preliminary conclusion that one of the main problems with regard to 'new generation texts' lies to date in the lack of implementation structures. Level linkages often seem to be missing, first in an interorganizational perspective, concerning the relationship between national affiliates and the respective EU umbrella organization, and secondly, in an intraorganizational perspective within (national) organizations. While representatives of national affiliates reported a good overall relationship with their European umbrella organizations, they also stated that there are a number of difficult aspects, related to rivalry or questions of authority, and the lack of feedback between EU umbrella organizations and national affiliates. This suggests that the interests of umbrella organizations' secretariats might differ from those of their national affiliates: for actors at the supranational level, the 'logic of influence' dominates the 'logic of membership'.

Concerning the intraorganizational dimension, examples of missing level linkages include, above all, the limited knowledge concerning the EU social dialogue and its results at lower levels than the central (head office) level within an organization: the issue of EU social dialogue is barely integrated in the internal structure, remaining rather isolated. In most of the cases analysed, there is only one person - if that - at the central level who deals with or is informed about the respective EU sectoral dialogue. Furthermore, according to the interviewees, at company or workplace level the functioning of EU social dialogue and its results are widely unknown. Hyman (2001: 59) put it 
in a nutshell for a comparable case: 'for example, the ETUC is an organisation of organisations... it is unclear how many grassroots trade union members are even aware of its existence, let alone recognise it as an authoritative actor on their behalf'.

Interviewees at national level admit, self-critically, that implementation and monitoring of 'new generation texts' are fairly problematic, as the EU social dialogue is not yet well embedded in the organizations' action and communication structures. However, these level linkages and implementation structures are essential if legally non-binding regulation is to be effective (Héritier, 2002: 203). Reasons related to actors' interests and attitudes concerning EU social dialogue may further hinder the development of implementation structures. This goal is even more difficult to attain to the extent that social partner organizations are comparatively weak, which, at sectoral level, is especially the case in many new Member States (Ghellab and Vaughan-Whitehead, 2003).

Apart from different national systems of industrial relations, however, central to all aspects discussed so far is the personal engagement of individuals for EU social dialogue at the various levels. EU social dialogue, in contrast to other processes stemming 'from the EU', such as EWCs or SEs, currently does not put direct pressure for action on national organizations. Therefore, EU social dialogue is dealt with as a topic of secondary importance which often means an additional workload and which is therefore highly dependent on individuals' specific interests. Nonetheless, supranational and, to a lesser extent, national social partners are increasingly discussing - both internally and bilaterally - how more systematic procedures of follow-up, implementation and evaluation of social dialogue results might be developed. A major incentive is to be found in the recent shift of attention towards the implementation and follow-up of 'new generation texts' forced by the Commission.

To sum up, establishing and institutionalizing linkages between levels - first of all between the supranational and the national level - constitutes a tricky manoeuvre within the existing framework of EU social dialogue. Such a goal could be attained, however, if two interrelated processes took place: first, the Commission must enforce the recent focus on the establishment of transparent outcomes and procedures, with an emphasis on implementation and monitoring. In this respect, the clear coupling of administrative, informational and financial support from the Commission with the establishment of such structures could constitute a real incentive for the social partners.

Secondly, social partner organizations must review their internal working methods with regard to communication and cooperation, in terms of both top-down and bottom-up processes - that is, EU secretariats with regard to their national affiliates and vice versa. Templates for new approaches in the field of social dialogue could in principle easily be found in other areas of activity of these organizations, such as industrial policy in the case of employers' organizations or policies on collective bargaining or EWCs in the case of trade unions.

However, the approaches of both the European Commission and the social partners are of course restricted by enforcement problems with regard to voluntary associations: neither supranational organizations nor their national affiliates can be obliged to act within the framework of such attempts to enhance level linkage. A lack of interest or, put differently, a perception that no value added will accrue to them on the part of some supranational or national organizations would therefore impede such attempts.

Finally, our findings shed some light on the practicality of attempts to classify social dialogue results in accordance with implementation and monitoring provisions and the actors involved (typologies provided by the European Commission and by the OSE - see above). The (formal) criterion for both typologies is the specification of monitoring procedures. Whereas the OSE typology additionally puts a clear emphasis on the addressees (European or public authorities vs the social partners themselves), the Commission typology puts more emphasis on the existence of follow-up provisions and the overall intention of a text. Unsurprisingly, both typologies encounter difficulties 
assigning texts to particular categories, since texts are often ambiguous, for example, concerning addressees or they may contain only very vague follow-up provisions. Nevertheless, although varying slightly, both typologies are fairly helpful for obtaining an overall picture of possible and existing social dialogue results.

However, both typologies suffer from a similar shortcoming when it comes to assessing the actual and potential 'impact' of social dialogue texts. Both typologies underestimate the potential and actual impact that joint texts in the 'tools' category may have in comparison to autonomous agreements or process-oriented texts, such as recommendations. For example, drawing on the OSE typology, Pochet (2008: 188) claims that, besides the binding agreements which account for 2 percent of all texts, at best 10 percent (the figure refers to the number of texts classified as recommendations during the years 1999-2007, thereby excluding 'tools') of documents issued in the sectoral dialogues 'are expected to have some impact at national level'.

'Tools' are highly valued and regarded as useful by all interviewees at different levels. They provide checklists and direct recommendations on a certain topic and therefore do not need to be 'transposed' or further elaborated by (national) actors to make them applicable in the daily work of social partners. As a positive side-effect, these kinds of results (could) also contribute to the urgently required raising of awareness among national actors at various 'lower' levels. Whereas 'tools' seem to be highly compatible with national social partners' fairly scarce resources, they might be more problematic for those organizations that fear a weakening of sectoral structures by strengthening or more directly involving also the company level.

In conclusion, the various findings presented above might be explained by the fact that many national affiliates of both European employers' and trade union organizations seem to be very interested in the lobbying element of EU sectoral social dialogue, whether as its principal or a complementary aspect. In this respect, above all the views of some national trade unions and their supranational organizations' official policies, aimed at further developing the regulation and bargaining function of EU sectoral social dialogue, seem to differ to a certain degree. According to our findings, some national trade union representatives are, at least, sceptical or not particularly eager to work towards more binding agreements; on the other hand, not all national employers seem to be generally opposed to reaching such agreements (this is also supported by recent developments in other sectoral dialogues, where social partner directives have been developed). A preference for 'new generation texts' and 'tools' can thus not only be attributed to employers; many national trade unions seem to be in favour of or satisfied with non-binding results, and with 'tools' in particular. A broad-brush classification of 'employer versus trade union preferences' does not, therefore, match the empirical picture of the complexity of interests and attitudes towards EU sectoral social dialogue. These may be contested not only between the 'two sides of industry', but also among national organizations affiliated to the same supranational organization and between national affiliates and their European umbrella organization. This finding does, however, not challenge the potential or intended use of 'new generation texts' and 'tools' by the involved social partners as means of improving the image of the sectoral social dialogue vis-à-vis the Commission and, therefore, as a means of securing the Commission's administrative, informational and financial support for the respective sectoral dialogue. A 'new generation text' or 'tool' itself would then tend to be primarily of symbolic value.

\section{Conclusion and outlook}

This article deals with recent developments in respect of EU social dialogue and focuses on two sectoral social dialogues at EU level and three Member States. How do the social partners cope 
with the implementation-oriented, but legally non-binding 'new generation texts' that have been concluded?

Empirical insights provided by the case studies support the following: whereas the interests and strategies of social partners are decisive in how they deal with 'new generation texts', the former are influenced by the national setting (that is, the domestic industrial relations system) and by the specific topic of a 'new generation text'. However, additional factors, such as type of text and the decisive role of individuals' commitment to EU social dialogue, have been highlighted. Overall, these factors define the options for social partner action and, therefore, have an impact on whether and how the implementation of EU social dialogue results takes place.

The findings indicate, overall, that the implementation of 'new generation texts' has, to date, been fairly limited in quantitative terms. The impact of an EU social partner document on national initiatives is hard to prove. The main problem is found to be the lack of adequate implementation structures, both in inter- and intraorganizational terms. Even if actors manage to establish these linkages in terms of implementation structures, institutionalization and systematic evaluation mechanisms, the major problem will remain of committing national affiliates to the implementation of 'new generation texts' or of motivating those affiliates to contribute to evaluation and monitoring exercises. In any case, as already mentioned, the well-known problem of self-reporting and self-evaluation - as illustrated in the case of the interprofessional telework agreement (ETUC et al., 2006) or in the various OMC policies (Zeitlin et al., 2005) - continues to exist in the form of a 'double filtering' of implementation records.

Moreover, it is clear that national affiliates value EU sectoral social dialogue: first and foremost, in many cases, the so-called 'tools' that have been elaborated and also the lobbying function of the dialogue. This applies not only to employers', but equally to trade unions' national affiliates. The picture of interests and attitudes concerning EU sectoral social dialogue is therefore complex. From an organization theory standpoint, the different perceptions and points of view among affiliates constitute an asset by providing excellent sources of wide-ranging knowledge and experiences and may strengthen the supranational organizations' representativeness. However, this may also pose considerable challenges for the development of common views and the promotion of policies - for example, concerning sectoral social dialogue agreements - and, therefore, for ensuring the efficiency of the supranational organization.

In terms of what they have achieved, sectoral social dialogues in recent years seem, overall, to have covered an even wider spectrum. This trend will continue, with some sectors focusing mainly on lobbying, others including the conclusion of joint commitments and yet others including the negotiation of social partner directives. It goes without saying that, as has been the case for the interprofessional social dialogue in the $1990 \mathrm{~s}$, the conclusion of social partner directives in particular will require the influence of the 'shadow of the law'. However, in the future it cannot be ruled out that the 'shadow of anarchy' (Börzel, 2007: 59), in the sense of non-regulation, may also facilitate more binding joint commitments.

As already mentioned, the evidence arising from the in-depth analysis presented here needs to be treated with caution with regard to its generalizability to other sectoral dialogues and countries. In addition, further comparative in-depth research is needed, in respect of which a number of important features must be highlighted. First, further research should focus on how implementation and evaluation structures could be established and strengthened. Secondly, to strengthen the comparative perspective, further research is needed on implementation in Member States with different national systems of industrial relations, including the new Member States. Thirdly, the comparative aspect should be further developed by analysing other sectoral dialogues at EU level. 
In addition, a closer look at the role of specific actors, such as (multinational) companies and European works councils, in dealing with EU social dialogue and its results would be fruitful to obtain a better understanding of current developments in EU social dialogue. Furthermore, research must take into account the relative novelty of 'new generation texts' and related processes and should not - as is often the case, at least implicitly - analyse and evaluate EU social dialogue by using the templates provided by national systems of industrial relations. Social dialogue at EU level does not present some sort of functional equivalent to national collective bargaining systems. Major national collective bargaining issues are excluded by the Treaty (Article 153 TFEU, former Article 137 TEC), and a right to strike or lock-out does not exist at EU level. Last but not least, the supranational organizations, with their specific structures and tasks, do not perform duties and responsibilities comparable to national organizations. Therefore, (autonomous) social dialogue at EU level constitutes a positive sum game or 'integrative bargaining' (Walton and McKersie, 1991), within the framework of which topics can find a general consensus within and between supranational organizations. Therefore, the two processes should not be used as mutual reference points, and social dialogue at EU level should rather be acknowledged and analysed as an evolving multi-actor and multi-level system sui generis. Consequently, any assessment of sectoral social dialogue at EU level must reveal the criteria applied. Assessing sectoral social dialogue in terms of lobbying activities, for instance, would lead to a much more positive result than an assessment in terms of regulatory capacity in the field of social policy.

\section{Acknowledgements}

The author would like to thank the editor, the two anonymous reviewers and the participants in the conference 'Transnational collective bargaining within a European multi-level system of industrial relations', organized by the European Trade Union Institute and the Université Libre de Bruxelles in February 2009, for valuable comments on an earlier version of this article.

\section{Funding}

Parts of this research were funded by the Hans Böckler Foundation.

\section{References}

Blanpain R (2007) The European Social Dialogue And Voluntary Framework Agreements. In: Blanpain R (ed.) European Framework Agreements and Telework: Law and Practice, A European and Comparative Study. The Hague: Kluwer, 31-39.

Branch A (2005) The Evolution of the European Social Dialogue Towards Greater Autonomy: Challenges and Potential Benefits. The International Journal of Comparative Labour Law and Industrial Relations 21(2): 321-346.

Börzel T (2007) Regieren ohne den Schatten der Hierarchie: Ein modernisierungstheoretischer Fehlschluss? In: Risse T and Lehmkuhl U (eds) Regieren ohne Staat? Governance in Räumen begrenzter Staatlichkeit. Baden-Baden: Nomos, 41-63.

Deakin S and Koukiadaki A (2007) The Capability Approach and the Reception of European Social Policy in the UK: The Case of the Telework Agreement (final report).

De Boer R, Benedictus H and van der Meer M (2005) Broadening without Intensification: The Added Value of the European Social and Sectoral Dialogue. European Journal of Industrial Relations 11(1): $51-70$.

Dølvik JE (1998) Neubestimmung der Grenzen der Solidarität? Der EGB, der soziale Dialog und die Europäisierung der Gewerkschaften in den 90er Jahren. In: Hoffmann R and Gabaglio E (eds) Ein offener 
Prozess. 11 Versuche über den europäischen Gewerkschaftsbund. Münster: Westfälisches Dampfboot, 297-359.

Dufresne A (2006) Sectoral Employer Strategies in the EU. Lobbying by Partners? In: Dufresne A, Degryse C and Pochet P (eds) The European Sectoral Social Dialogue. Actors, Developments and Challenges. Brussels: PIE Peter Lang, 249-279.

Dufresne A, Degryse C and Pochet P (eds) (2006) The European Sectoral Social Dialogue. Actors, Developments and Challenges. Brussels: PIE Peter Lang.

ETUC, UNICE/UEAPME and CEEP (2006) Implementation of the European Framework Agreement on Telework. Report by the European Social Partners. Available at: http://ec.europa.eu/employmentsocial/ news/2006/oct/telework implementation report en.pdf.

European Commission (1993) Communication concerning the application of the Agreement on social policy. $\operatorname{COM}(93) 600$ final, 14 December 1993, Brussels.

European Commission (2004) Partnership for change in an enlarged Europe-Enhancing the contribution of European social dialogue. Communication from the Commission, COM(2004) 557 final, 12 August 2004, Brussels.

European Commission (2009) Industrial Relations in Europe 2008. Luxembourg: Office for the official publications of the European Union.

European Commission (2010) Commission Staff Working Document on the functioning and potential of European sectoral social dialogue. SEC(2010) 964 final, 22 July 2010, Brussels.

European Council (2000) Presidency Conclusions. Lisbon European Council, 23 and 24 March 2000. Available at: www.consilium.europa.eu/ueDocs/cms Data/docs/pressData/en/ec/00100-r1.en0.htm.

Falkner G, Treib O, Hartlapp M and Leiber S (2005) Complying with Europe. EU Harmonisation and Soft Law in the Member States. Cambridge: Cambridge University Press.

Ghellab Y and Vaughan-Whitehead D (2003) Sectoral Social Dialogue: A Link to Be Strengthened. In: Ghellab Y and Vaughan-Whitehead D (eds) Sectoral Social Dialogue in Future EU Member States: The Weakest Link. Budapest: ILO, 1-42.

Héritier A (2002) New Modes of Governance in Europe: Policy-Making without Legislating? In: Héritier A (ed.) Common Goods. Reinventing European and International Governance. Lanham: Rowman \& Littlefield, 185-206.

Hyman R (2001) Some problems of partnership and dilemmas of dialogue. In: Kjærgaard C and Westphalen S-A (eds) From collective bargaining to social partnerships: New roles of the social partners in Europe. Copenhagen: The Copenhagen Centre, 39-59.

Jacobi O and Kirton-Darling J (2005) Creating perspectives, negotiating social Europe. Transfer 11(3): 333-342.

Keller B (2003) The Supranational Regulation of Employment Relations - the Example of the EU. In: Hoffmann R, Jacobi O, Keller B and Weiss M (eds) European Integration as a Social Experiment in a Globalized World. Düsseldorf: Hans-Böckler-Stiftung, 47-67.

Keller B (2005) Europeanisation at sectoral level. Empirical results and missing perspectives. Transfer 11(3): 397-408.

Larsen TP and Andersen SK (2007) A New Mode of European Regulation? The Implementation of the Autonomous Framework Agreement on Telework in Five Countries. European Journal of Industrial Relations 13(2): 181-198.

Larsen TP and Navrbjerg SE (2009) Recent European challenges and the Danish collective agreement model. $A$ research paper focusing on the banking sector and the Confederation of Professionals in Denmark. October 2009. Copenhagen: FAOS.

Leiber S (2005) Europäische Sozialpolitik und nationale Sozialpartnerschaft. Frankfurt/Main: Campus.

Léonard E (2008) European sectoral social dialogue: An analytical framework. European Journal of Industrial Relations 14(4): 401-419. 
Léonard E, Erne R, Marginson P, Smismans S and Tilly P (2007) New structures, forms and processes of governance in European industrial relations. Luxembourg: European Foundation for the Improvement of Living and Working Conditions.

Marginson P (2005) Industrial Relations at European Sectoral Level: The Weak Link? Economic and Industrial Democracy 26(4): 511-540.

Mayntz R and Scharpf FW (1995) Der Ansatz des akteurzentrierten Institutionalismus. In: Mayntz R and Scharpf FW (eds) Gesellschaftliche Selbstregelung und politische Steuerung. Frankfurt/Main: Campus, $39-72$.

Müller-Jentsch W (2004) Theoretical Approaches to Industrial Relations. In: Kaufman BE (ed.) Theoretical Perspectives on Work and the Employment Relationship. Champaign: IRRA, 1-40.

Murhem S (2008) Swedish Trade Unions and European Sectoral Level Industrial Relations - Goals and Strategies. In: Rönnmar M (ed.) EU Industrial Relations v. National Industrial Relations. Comparative and Interdisciplinary Perspectives. Alphen aan den Rijn: Wolters Kluwer, 105-117.

Niforou C (2008) The role of trade unions in the implementation of autonomous framework agreements. Warwick Papers in Industrial Relations No. 87.

Pochet P (2007) European social dialogue - an empty shell or a tool for social embedding? In: Jacobi O, Jepsen M, Keller B and Weiss M (eds) Social Embedding and the Integration of Markets. An Opportunity for Transnational Trade Union Action or an Impossible Task? Düsseldorf: Hans-Böckler-Stiftung, 147-165.

Pochet P (2008) Sectoral social dialogue: a review of the past three years. In: Degryse C and Pochet P (eds) Social Developments in the European Union 2007. Ninth annual report. Brussels: ETUI-REHS, 173-193.

Pochet P, Peeters A, Léonard E and Perin E (2009) Dynamics of European sectoral social dialogue. Luxembourg: European Foundation for the Improvement of Living and Working Conditions.

Prosser T (2007) Europeanization through procedures and practices? The implementations of the Framework Agreements on Telework and Work-related stress in Denmark and UK. FAOS Working Paper No. 077.

Schmitter PC and Streeck W (1999) The Organization of Business Interests. Studying the Associative Action of Business in Advanced Industrial Societies. MPIfG Discussion Paper 99/1.

Smismans S (2008) The European Social Dialogue in the Shadow of Hierarchy. Journal of Public Policy 28(1): 161-180.

Visser J and Ramos Martin N (2008) Expert Report on the implementation of the Social Partner's Framework Agreement on Telework. Amsterdam: Amsterdam Institute for Advanced Labour Studies.

Walton RE and McKersie RB (1991) A Behavioral Theory of Labor Negotiations (2nd edition). New York: McGraw-Hill.

Weber S (2008) Autonome Sozialdialoge auf EU-Ebene. Zur Problematik der Implementation von 'Texten der neuen Generation'. Industrielle Beziehungen 15(1): 53-75.

Weber S (2010) Sektorale Sozialdialoge als europäisches Mehrebenensystem: Regulierung durch private Akteure. In: Busch K (ed.) Wirtschaftliche und soziale Integration in der Europäischen Union: Handlungsräume für korporative Akteure. Baden-Baden: Nomos, 153-176.

Zeitlin J, Pochet P and Magnusson L (eds) (2005) The Open Method of Coordination in Action. The European Employment and Social Inclusion Strategies. Brussels: PIE Peter Lang. 